\title{
Seasonal/Interannual Variations of Carbon Sequestration and Carbon Emission in a Warm-Season Perennial Grassland
}

\author{
Deepa Dhital, ${ }^{1}$ Tomoharu Inoue, ${ }^{2}$ and Hiroshi Koizumi ${ }^{2}$ \\ ${ }^{1}$ Nepal Academy of Science and Technology (NAST), GPO Box 3323, Khumaltar, Lalitpur, Nepal \\ ${ }^{2}$ Faculty of Education and Integrated Arts and Sciences, Waseda University, Shinjuku 162-8480, Japan \\ Correspondence should be addressed to Deepa Dhital; dhital.deepa@gmail.com
}

Received 25 March 2014; Accepted 16 October 2014; Published 11 November 2014

Academic Editor: Wen-Cheng Liu

Copyright (C) 2014 Deepa Dhital et al. This is an open access article distributed under the Creative Commons Attribution License, which permits unrestricted use, distribution, and reproduction in any medium, provided the original work is properly cited.

Carbon sequestration and carbon emission are processes of ecosystem carbon cycling that can be affected while land area converted to grassland resulting in increased soil carbon storage and below-ground respiration. Discerning the importance of carbon cycle in grassland, we aimed to estimate carbon sequestration in photosynthesis and carbon emission in respiration from soil, root, and microbes, for four consecutive years (2007-2010) in a warm-season perennial grassland, Japan. Soil carbon emission increased with increasing growing season temperature which ranged from 438 to $1642 \mathrm{mg} \mathrm{CO}_{2} \mathrm{~m}^{-2} \mathrm{~h}^{-1}$. Four years' average soil carbon emission for growing season, nongrowing season, and annual emission was 1123,364 , and $1488 \mathrm{~g} \mathrm{C} \mathrm{m}^{-2}$, respectively. Nongrowing and snow covered season soil carbon emission contributed $23-25 \%$ and $14-17 \%$ to the annual emission. Above-ground biomass varied seasonally and variation in green biomass affected soil carbon emission with increasing temperature and precipitation. Temperature effect on root carbon emission contributed about $1 / 4$ th of the total soil carbon emission. Variation in soil and root carbon emission is affected by below-ground biomass. Long-term estimation concluded that seasonal and interannual variations in carbon sequestration and emission are very common in grassland ecosystem.

\section{Introduction}

Carbon sequestration and emission can be affected while the ecosystem land area converted to the grassland [1-3], resulting in increased soil carbon storage $[4,5]$, belowground respiration, and carbon cycling [6]. Land area converted to grassland has been reported to affect ecosystem carbon balance in short term through increased variations in ecosystem carbon cycling [7-9]. Moreover, one of the major long-term effects of such land conversion is the reduced carbon sink strength of grassland ecosystems [10]. Grasslands are able to store $10-30 \%$ of global soil organic carbon due to its large coverage (40\%) of the earth's terrestrial surface and are considered to sequester large amounts of carbon from the atmosphere and hence acquire significant sink/source capacity of the ecosystem and play a major role in the global carbon balance [11-13].

Soil as a whole is a large pool of atmospheric carbon. Globally, it accumulates $1500-2000$ petagrams (Pg carbon, $1 \mathrm{Pg}=10^{15} \mathrm{~g}$ ) in the form of soil organic carbon in the upper $1 \mathrm{~m}$ of soil $[14,15]$ or even greater [16], which is at least three times larger than atmospheric carbon. Small variation in carbon storage in grassland soil will greatly affect the concentration of atmospheric carbon and the trend of regional or global climate change $[17,18]$, although grassland acts as a sink/source of atmospheric carbon that depends on its grazing intensity, land use, management, and climate [19]. The biogeochemical process (carbon cycling) that controls the exchange of carbon between soil and atmosphere is not yet well understood [20]. The amount of carbon during sequestration and emission is not the highest for grasslands compared to forest, but their large land mass plays an important role in global carbon storage and cycling [21]. On a global scale, grasslands cover approximately the same area as forests [22], but very less attention has been given to the grassland carbon cycling which may have a significant role in balancing the global carbon budget $[23,24]$.

Soils are considered to sequester large amounts of carbon from the atmosphere via plant photosynthesis and emit carbon via respiration by plant and microorganisms and their balance determining whether the ecosystem is a carbon sink/source [25-27]. Thus this process has been extensively 
investigated to improve the understanding of carbon cycling in terrestrial ecosystems. Soil carbon emission is very sensitive to environmental conditions importantly influenced by soil temperature [28] and availability of soil water [29] that have potential role either to amplify global warming $[25,30]$ or to mitigate climate change due to enhanced soil carbon sequestration and reduced emission [31, 32]. Therefore, it is essential to improve our understanding of the variations in carbon sequestration and carbon emission in ecosystem for better management of these potentials. Because of high seasonal [33-35] and interannual [36-42] variations of carbon sequestration and carbon emission, continuous and long-term studies in local scale are necessary for evaluating the carbon budget on the global scale [12].

Considering a major emission between the atmosphere and land, soil carbon emission is estimated to be 50$78 \mathrm{Pg} \mathrm{Cy}^{-1}$ and accounted $25 \%$ of the global carbon exchange [43-45]. Accurate estimation of soil carbon emission thus becomes one of the important issues in the global carbon cycle. The important factors determining seasonal and interannual variations in soil carbon emission are temperature and soil moisture in grasslands [36, 46-48]. Generally, soil carbon emissions increase through respiration with temperature; exponential [47, 49-52] power [50] and linear functions [53] are used to describe the temperature function of soil carbon emission. Similarly, carbon sequestration increases through photosynthesis via biomasses with increasing soil moisture in growing season [28, 54-58]. In carbon cycling, carbon sequestration and emission between ecosystem and atmosphere in grassland can be roughly estimated using environmental variables for short period and for the confounding result, long-term continued measurements and estimation for years are required. So far, very few literatures are available regarding information on perennial grassland ecosystem relating to long-term estimation of carbon sequestration (uptake), emission (release), and its dependence on climate. Hence long-term measurements and estimation for years holds significant scientific importance to have quantitative study on carbon cycling between soil and atmosphere as well as prediction on its future possible changes [59]. The most important link in grassland carbon cycling is soil carbon emissions to atmosphere through respiration and the amount of soil carbon determines directly soil carbon turnover rate [60].

Knowing the importance of carbon cycling in grassland and its implications on present climate change, we aimed to measure and estimate the carbon sequestration during photosynthesis from plant biomass and carbon emission during respiration from soil including root and microbial respiration for four consecutive years in a warm-season perennial grassland. This perennial grassland sequesters carbon only during the growing season that is half of the year (May-October) and emits carbon throughout the year, but not in same amount. Except early/late growing season (April/November) and growing season (May-October), the grassland is covered with snow in winter season (DecemberMarch). Thus, overall goal of this study was to estimate and determine the seasonal/interannual variation of carbon sequestration and carbon emission in the grassland with less climatic variability (i.e., temperature and precipitation) between the years from 2007 to 2010 .

\section{Materials and Methods}

2.1. Site Description. This study was conducted in permanent grassland located near the Takayama Experimental Field Station $\left(36^{\circ} 08^{\prime} \mathrm{N}, 137^{\circ} 25^{\prime} \mathrm{E}\right.$, elevation $1,342 \mathrm{~m}$ a.s.l.) from 2007 to 2010. The site is about $15 \mathrm{~km}$ east of Takayama City in central Japan and it was established in 1913 which occupies 17.9 ha including small land area covered by forest to provide grazing land for cows. Every year, cattle enter in June and leave in October in the site; hence grazing period occurs for five months in a year. It has cool-temperate climate with high diurnal temperature and plentiful rainfall in summer. The mean air temperature was $7.2^{\circ} \mathrm{C}$ and annual precipitation was $2073.5 \mathrm{~mm}$ from 2001 to 2010 recorded at the Takayama Experimental Field Station $(100 \mathrm{~m}$ from the study site). Temperature and total monthly precipitation increases with the progress of growing season starting from May and decreases from the end of October.

The site is dominated by a warm-season perennial $\mathrm{C}_{4}$ grass Zoysia japonica and other grass species such as Ranunculus japonicus, Trifolium repens, and Poa spp. are also common. Z. japonica begins to grow in early May and reaches its seasonal peak in summer between mid-July and September. It is very active during the period of high temperature and precipitation, whereas growth of the other grass species peaks in June [55].

2.2. Soil Carbon Emission Measurement. The measurement of soil carbon emission $\left(\mathrm{CO}_{2}\right)$ was conducted monthly using a portable photosynthesis system (LI-6400; Li-Cor, Lincoln, NE) fitted with a soil respiration chamber (LI-6400-09) from May to October, 2007, in the study site. The chamber $(12 \mathrm{~cm}$ diameter and $15 \mathrm{~cm}$ height) was fitted to a soil collar ( $n=$ 20) made of polythene, which was inserted into the soil one day before the measurements in order to remove some installation effects. All the measurements were made between 11:00 and 12:00 AM in each month to avoid diurnal fluctuations. Three consecutive measurements were conducted on each collar without removing the chamber and average of three measurements was taken as the representative value of each collar. Soil temperatures between 3 and $5 \mathrm{~cm}$ depth were measured during soil carbon emission measurements in each time. Volumetric soil water content ( $5 \mathrm{~cm}$ soil depth) was also measured by the time-domain reflectometry method (TRIME, IMKO, Ettlingen, Germany) within the soil collar at the time of soil carbon emission measurements. Continuous measurements of temperature between 3 and $5 \mathrm{~cm}$ soil depth were also recorded in the site at $1 \mathrm{~h}$ intervals over the 4 years of our study period by using Stowaway TidbiT Temperature Data Logger, Onset Computer, MA.

The relationship between soil carbon emission and soil temperature was analyzed by regression analysis. The sensitivity of soil carbon emission to soil temperature was assessed by fitting exponential functions to the data as follows:

$$
f(T)=a e^{b T},
$$




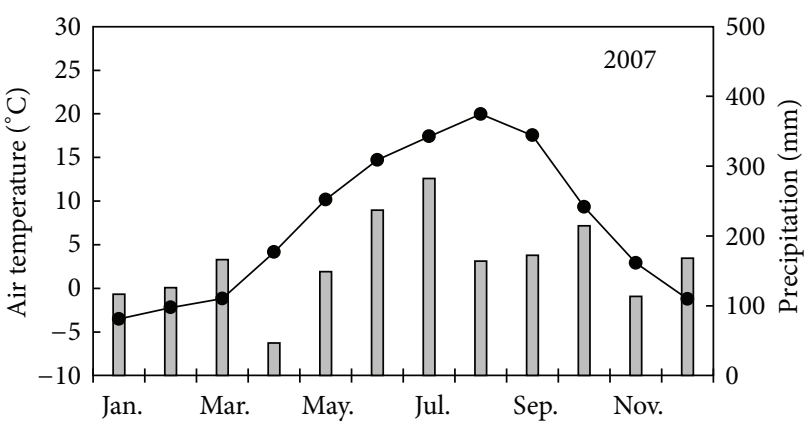

(a)

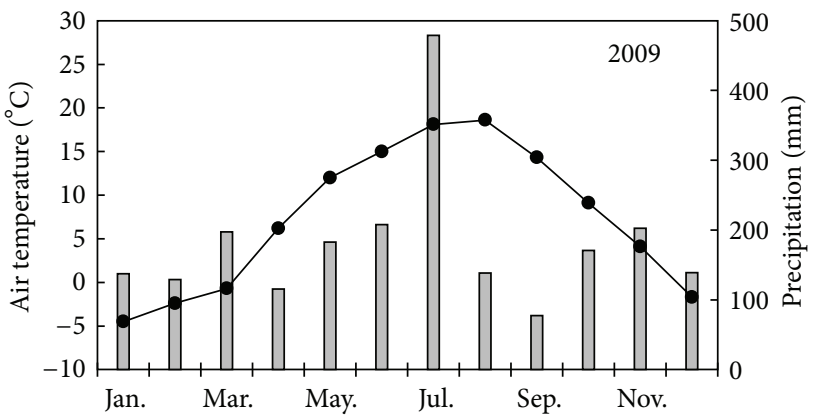

(c)

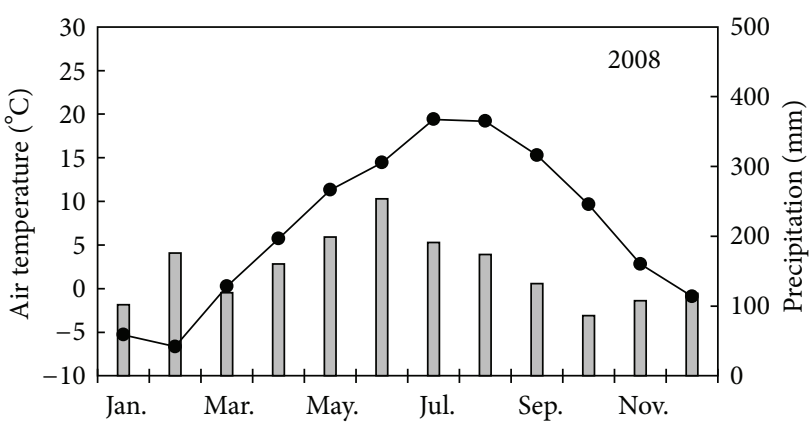

(b)

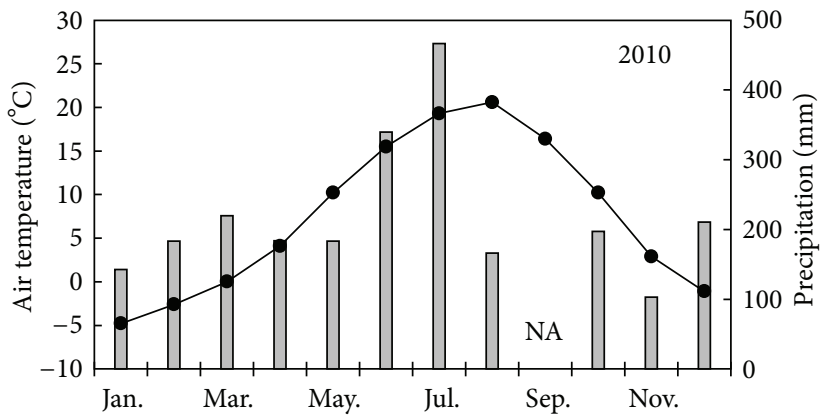

(d)

FIGURE 1: Mean monthly air temperature (filled circles) and monthly total precipitation (bars) recorded in (a) 2007, (b) 2008, (c) 2009, and (d) 2010 at the Takayama Experimental Field Station, Gifu University. NA = data not available.

where $[f(T)]$ is the predicted soil carbon emission rate (mg $\left.\mathrm{CO}_{2} \mathrm{~m}^{-2} \mathrm{~h}^{-1}\right)$ at ST $\left(\mathrm{T},{ }^{\circ} \mathrm{C}\right)$ at a depth of $3-5 \mathrm{~cm}, a$ represents the intercept of soil carbon emission rate when ST is zero, and $b$ represents the temperature sensitivity of soil carbon emission. The $b$ value was used to calculate a coefficient of temperature sensitivity (respiration quotient, $Q_{10}$ ), which describes the change in soil carbon emission over a $10^{\circ} \mathrm{C}$ increase in soil temperature by

$$
Q_{10}=e^{10 b} .
$$

Values of the parameters (i.e., $a, b$, and $Q_{10}$ ) derived from the seasonal data sets reflect the effects of temperature and other covarying factors on soil carbon emission rate. Thus, an apparent $Q_{10}$ is used to denote the derived temperature sensitivity of soil carbon emission.

2.3. Root Carbon Emission Measurement. An open-flow gasexchange system was used to measure root carbon emission in the laboratory. The measurements were conducted by using roots sampled from field during midgrowing season in August to determine the temperature effect on root carbon emission. Initially, sampled roots $(n=3)$ from soil block were washed carefully to remove the soil and separated into fine roots and rhizomes. Measurements were made within $1 \mathrm{~h}$ of root sorting from the soil. Roots were placed in a cylindrical chamber (polythene pipe; $3 \mathrm{~cm}$ in diameter, $25 \mathrm{~cm}$ in length) connected to the respiration measurement system, and ambient air at a rate of $0.5 \mathrm{~L} \mathrm{~min}^{-1}$ was flowed into the system. The temperature inside the chamber was monitored using a copper-constantan thermocouple and controlled by keeping it in a water bath regulated by a condenser (Coolnit C80R, Taiten, Japan) to maintain the roots at five different temperatures: $7,12,17,22$, and $27^{\circ} \mathrm{C}$. The $\mathrm{CO}_{2}$ concentrations of the reference gas and a mixture of sample and reference gas were measured using a $\mathrm{CO}_{2} / \mathrm{H}_{2} \mathrm{O}$ gas analyzer (LI-7000, Li-Cor) to determine the $\mathrm{CO}_{2}$ concentration of the sample gas. After the root carbon emission measurements, the root samples were oven-dried and weighed to calculate the rate of respiration per unit of dry root biomass.

2.4. Plant Biomass Measurement. Plant biomass was measured monthly during the growing season between May and October from 2007 to 2010 by removing the aboveground plant biomass at ground level and below-ground plant biomass up to $20 \mathrm{~cm}$ soil depth in the grazing area. The aboveground plant parts were sampled in five $20 \times 20 \mathrm{~cm}$ quadrants, oven-dried at $70^{\circ} \mathrm{C}$ for $72 \mathrm{~h}$, and weighed to calculate the dry weight. Similarly, below-ground parts were sampled in five 20 $\times 10 \mathrm{~cm}$ soil blocks, washed with water, and then hand-sorted into fine root and rhizome. These samples were oven-dried at $70^{\circ} \mathrm{C}$ for $72 \mathrm{~h}$ and weighed separately.

\section{Results}

3.1. Air/Soil Temperature and Precipitation. Figure 1 represents mean monthly air temperature and monthly total precipitation in 2007, 2008, 2009, and 2010 during the study period. Lowest air temperature was recorded at $-3.5,-5.2$, -4.5 , and $-4.8^{\circ} \mathrm{C}$ in January and these start to increase continuously up to maximum air temperature at 19.9, 19.2, 


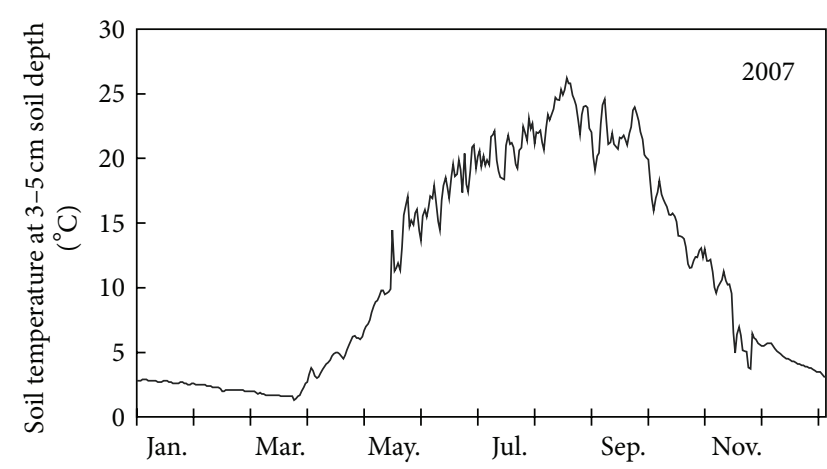

(a)

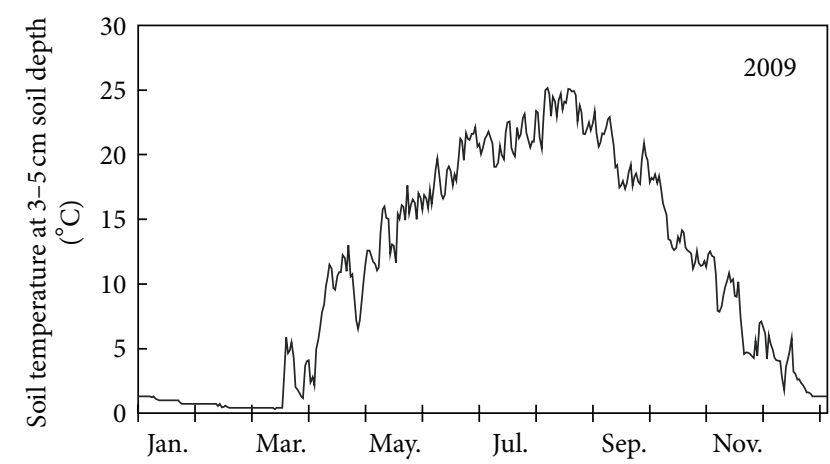

(c)

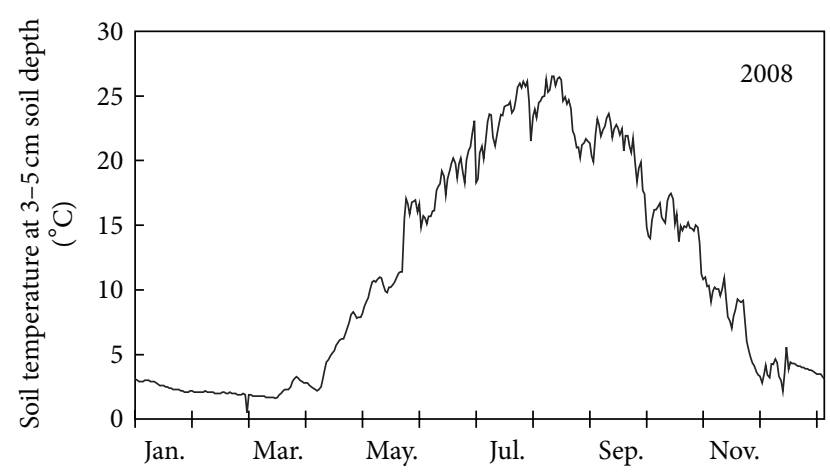

(b)

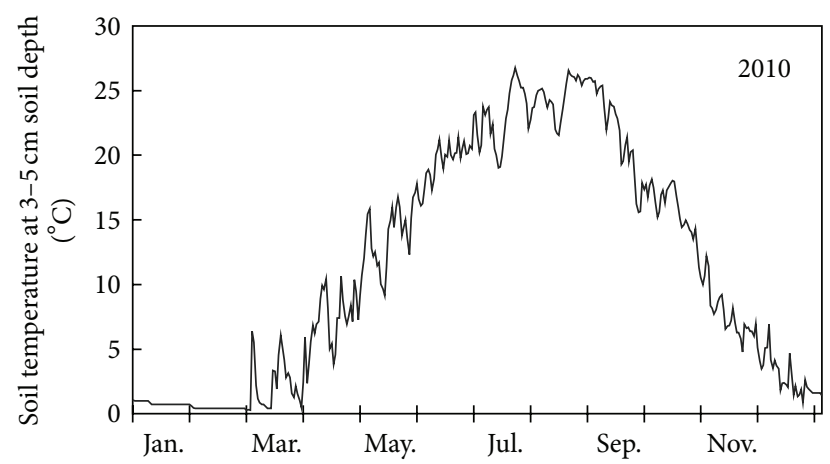

(d)

FIGURE 2: Seasonal changes of daily soil temperature at 3-5 cm soil depth in (a) 2007, (b) 2008, (c) 2009, and (d) 2010.

18.6, and $20.6^{\circ} \mathrm{C}$ in August 2007, 2008, 2009, and 2010, respectively, and also reached its maximum at $19.4^{\circ} \mathrm{C}$ in July 2008. Similarly, maximum monthly total precipitation was recorded in July 2007, 2009, and 2010, and in 2008 it was in June. The highest precipitation was recorded at $479 \mathrm{~mm} /$ month in July 2009 among the years. Daily soil temperature at $3-5 \mathrm{~cm}$ soil depth recorded from 1 January 2007 to 30 December 2010 was shown in Figure 2. The soil temperature started to increase from March and reached its maximum in August and then started to decrease with the end of growing season, responding to changes in air temperature (Figure 1). Recorded maximum soil temperature was $26.2^{\circ} \mathrm{C}$ in 16 August, $26.5^{\circ} \mathrm{C}$ in 9,10 August, $25.2^{\circ} \mathrm{C}$ in 5 August, $26.8^{\circ} \mathrm{C}$ in $22 \mathrm{July}$, and $26.6^{\circ} \mathrm{C}$ in 19 August in 2007 , 2008, 2009, and 2010, respectively. Among four years the highest soil temperature was reached in July and August 2010. However, the maximum monthly average soil temperature was $23.4,23.6,23.4$, and $24.7^{\circ} \mathrm{C}$ in August for all the years.

3.2. Soil Carbon Emission. Figure 3(a) shows the significant positive exponential relationship between soil carbon emission and soil temperature $(3-5 \mathrm{~cm}$ soil depth) and higher correlation value $\left(R^{2}=0.83\right)$ has been obtained during the growing period (May-October) in 2007. Soil carbon emissions were strongly dependent on the seasonal variations of soil temperature and the values ranging from 438 to $1642 \mathrm{mg} \mathrm{CO}_{2} \mathrm{~m}^{-2} \mathrm{~h}^{-1}$ were obtained in May and August, respectively. A coefficient of temperature sensitivity (respiration quotient, $Q_{10}$ ) of soil carbon emission was 2.1 throughout the measurement period (2). However, the relationship between soil carbon emission and soil water content during the growing season in 2007 was not significant $\left(R^{2}=0.018\right)$ and scattered relation was explained by Figure 3(b).

Seasonal and interannual variations of soil carbon emission in 2007, 2008, 2009, and 2010 were represented in Figure 4 and their monthly average values were estimated by using exponential function obtained in Figure 3(a)(1). The soil carbon emissions were lower for the first four months (Jan.-Apr.) and they started to increase with increasing temperature and with the progress of growing season, and they reached maximum in August and again decreased with decreasing temperature towards the end of growing season. Higher soil carbon emissions were obtained during growing season from May to October and the values were comparatively variable in different years. But, nongrowing season soil carbon emissions were nearly equal and comparable. Therefore, seasonal variations of soil carbon emissions were very clear in four years and they were confounded with soil temperature.

Values of monthly average soil carbon emissions in 2007, 2008,2009 , and 2010 were slightly variable even in the same month in different years because of the variations in soil temperature. However, the range of soil carbon emissions in each month for all years was the same and they have followed similar trend of seasonal vitiation so that values are comparable to each other (Figure 4). Maximum monthly average soil carbon emissions were estimated at 1285, 1305, 


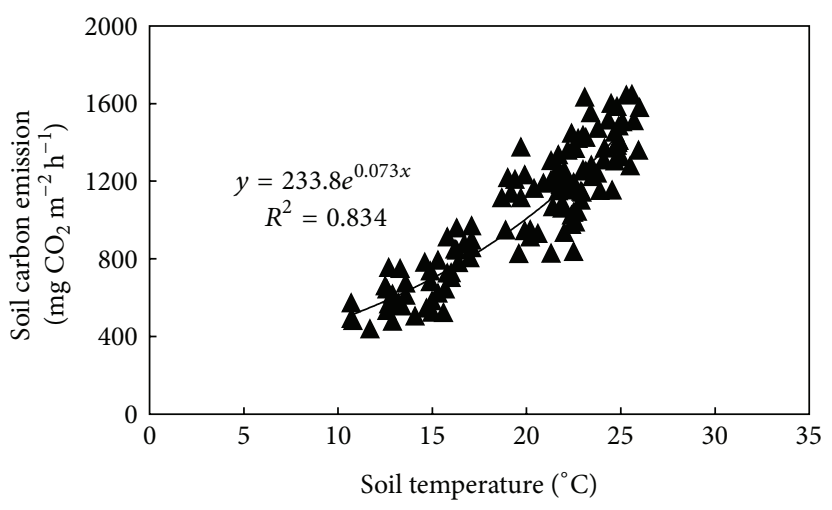

(a)

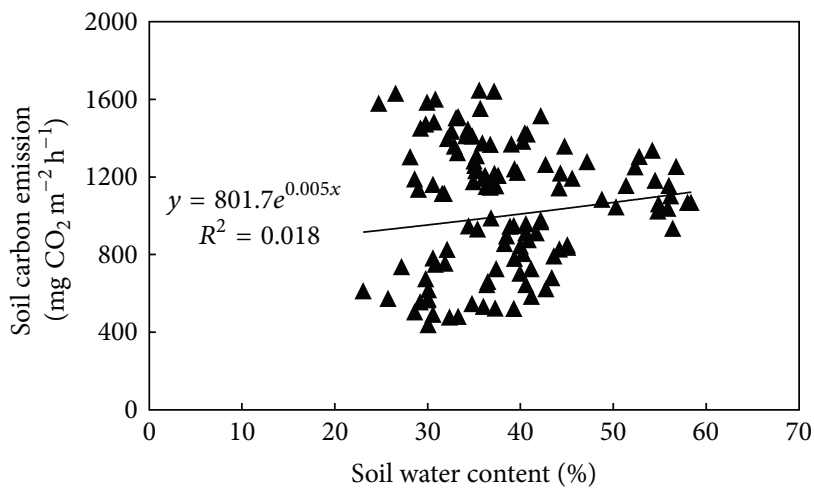

(b)

FIGURE 3: Relationship between (a) soil carbon emission and soil temperature ( $3-5 \mathrm{~cm}$ soil depth) and (b) soil carbon emission and soil water content in a growing season $2007, n=20$.

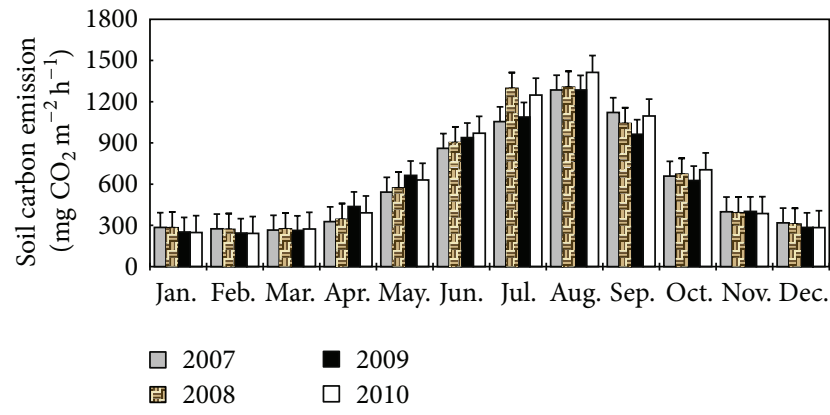

FIGURE 4: Seasonal and interannual variations of soil carbon emission (monthly average) in 2007, 2008, 2009, and 2010.

1285, and $1414 \mathrm{mg} \mathrm{CO}_{2} \mathrm{~m}^{-2} \mathrm{~h}^{-1}$ in August 2007, 2008, 2009, and 2010, respectively. Relatively highest soil carbon emission $\left(1414 \mathrm{mg} \mathrm{CO}_{2} \mathrm{~m}^{-2} \mathrm{~h}^{-1}\right.$ ) was obtained in August $2010 \mathrm{com}-$ pared to previous years owing to higher soil temperature recorded in that time of the year.

The growing season (May-Oct.) soil carbon emissions were estimated at 1082, 1134, 1090, and $1187 \mathrm{~g} \mathrm{C} \mathrm{m}^{-2}$, nongrowing season (Nov.-Apr.) carbon emissions were 366, 366, 369 , and $357 \mathrm{~g} \mathrm{C} \mathrm{m}^{-2}$, and annual soil carbon emissions were $1448,1500,1459$, and $1544 \mathrm{~g} \mathrm{C} \mathrm{m}^{-2}$ in 2007, 2008, 2009, and 2010 , respectively, as represented in Table 1 . The values show that growing season and annual soil carbon emission in consecutive years are variable and not exactly the same but nongrowing season soil carbon emission in years were nearly stable and equal. Contribution of nongrowing season and snow covered season (Nov.-Feb.) soil carbon emission to the annual soil carbon emission was 23 to $25 \%$ and 14 to $17 \%$, respectively. We estimated that four consecutive years' (2007 to 2010) average soil carbon emissions of the grassland were 1123 , 364, and $1488 \mathrm{~g} \mathrm{C} \mathrm{m}^{-2}$ for growing season, nongrowing season, and annual emission, respectively.

3.3. Plant Biomass. Carbon sequestration in ecosystem followed accumulation of plant above-ground and belowground biomass through growth. The above-ground biomass varied seasonally (one-way repeated-measures ANOVA; $P<$

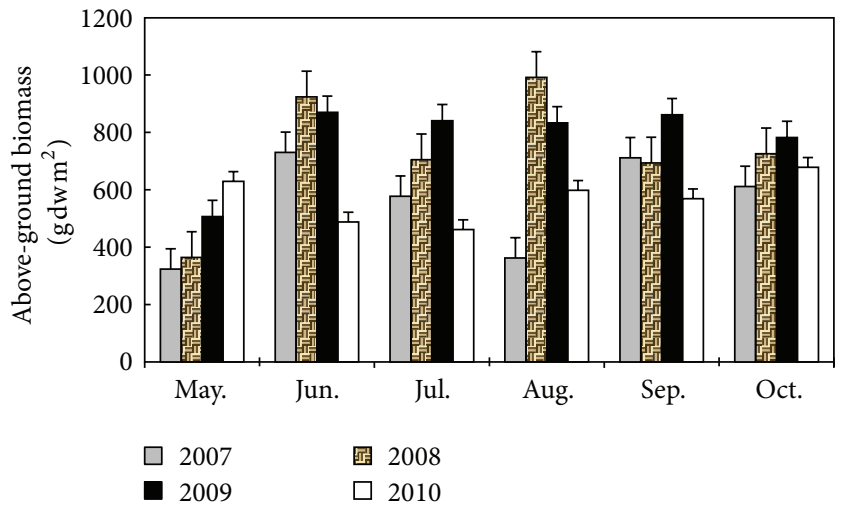

FIGURE 5: Seasonal and interannual variations of above-ground total biomass (green + dead) in 2007, 2008, 2009, and 2010. Error bars are standard errors of the measured value.

TABLE 1: Estimation of soil carbon emission $\left(\mathrm{g} \mathrm{C} \mathrm{m}^{-2}\right)$ in 2007, 2008, 2009, and 2010 during the period of growing season, nongrowing season, and annual emission of the grassland.

\begin{tabular}{|c|c|c|c|}
\hline \multirow[b]{2}{*}{ Year } & \multicolumn{3}{|c|}{ Carbon emission from soil $\left(\mathrm{g} \mathrm{C} \mathrm{m}^{-2}\right)$} \\
\hline & $\begin{array}{c}\text { Growing } \\
\text { season }\end{array}$ & $\begin{array}{c}\text { Nongrowing } \\
\text { season }\end{array}$ & $\begin{array}{l}\text { Annual } \\
\text { emission }\end{array}$ \\
\hline 2007 & 1082 & 366 & 1448 \\
\hline 2008 & 1134 & 366 & 1500 \\
\hline 2009 & 1090 & 369 & 1459 \\
\hline 2010 & 1187 & 357 & 1544 \\
\hline Average (2007-2010) & 1123 & 364 & 1488 \\
\hline
\end{tabular}

$0.0001)$ as in Figure 5. The green biomass starts to grow from $49.5,108.5,152.4$, and $57.9 \mathrm{~g} \mathrm{dw} \mathrm{m}^{-2}$ (dead parts from previous year were not included) and reached its (dead + green) peak at $711.8,991.5,869.9$, and $678.3 \mathrm{~g} \mathrm{dw} \mathrm{m}^{-2}$ in 2007, 2008, 2009, and 2010 , respectively. The above-ground biomass production in 2008 was found highest in August among the years and it is lower during June, July, August, and September 2010 in its peak growing period. Similarly, below-ground biomass also 


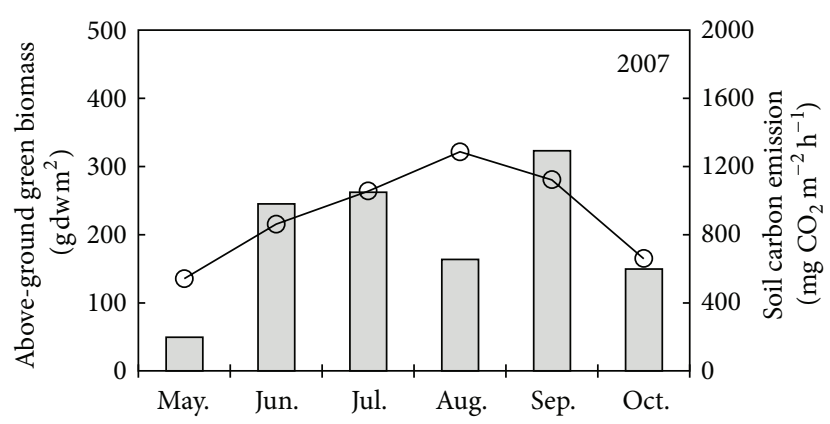

(a)

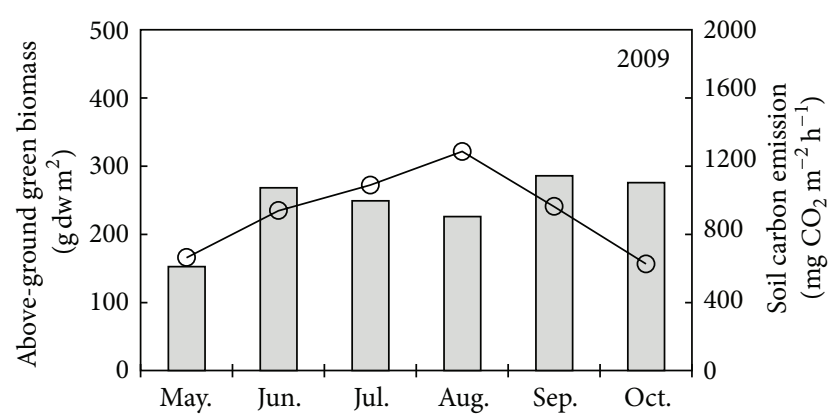

(c)

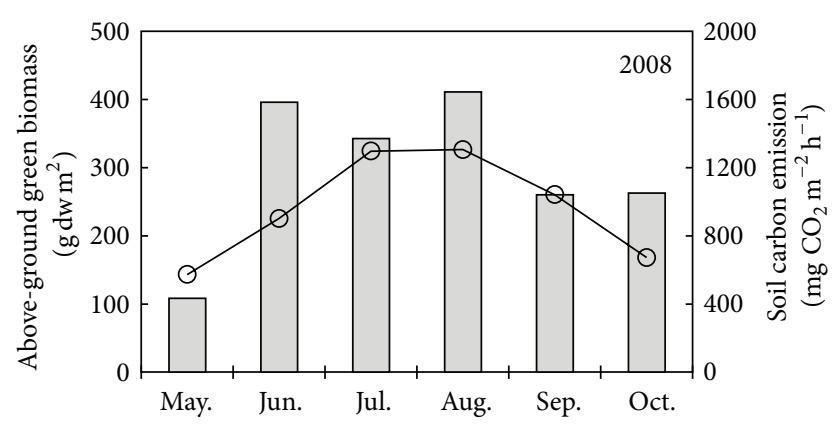

(b)

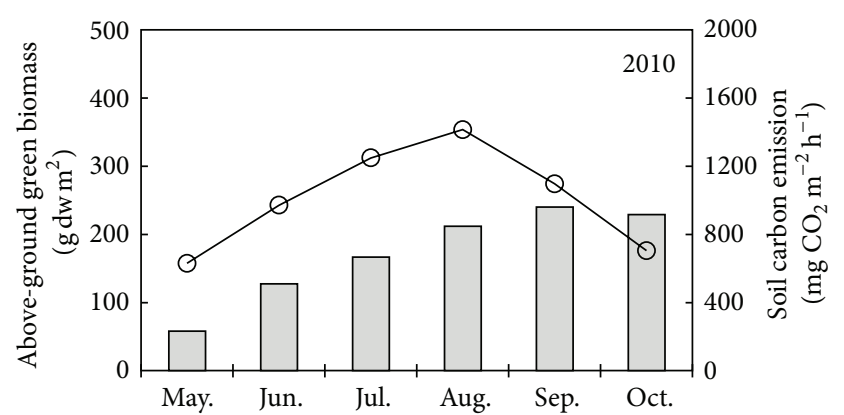

(d)

FIGURE 6: Variations of soil carbon emission with the changes of above-ground green biomass in (a) 2007, (b) 2008, (c) 2009, and (d) 2010 growing season.

varied seasonally with the variations of growing season and it ranged from 1074.5 to $1235.0 \mathrm{~g} \mathrm{dw} \mathrm{m}^{-2}$ in consecutive four years.

Figure 6 represents the variations of soil carbon emission with the changes in above-ground green biomass during growing season in 2007, 2008, 2009, and 2010 and shows that green biomass was increased with increasing growing season. In the meantime, some amount of green biomass was removed from grassland in grazing by cattle. Therefore, soil carbon emission was influenced with the change in growing season; it increases with increasing above-ground green biomass and soil temperature (Figure 3(a)). And plant biomass increases with increasing soil water content and temperature; the unclear effect of soil water content on soil carbon emission (Figure 3(b)) in this study is not much far from its positive relation. However, higher precipitation suppresses soil carbon emission due to soil capillary effect and higher temperature with removing water availability in soil affects plant growth and soil carbon emission. The above-ground green biomass was peaked at 322.9, 285.9, and $240.2 \mathrm{~g} \mathrm{dw} \mathrm{m}^{-2}$ in September 2007, 2009, and 2010, respectively, and it was peaked at $411.0 \mathrm{~g} \mathrm{dw} \mathrm{m}^{-2}$ in August 2008.

3.4. Root Carbon Emission. The temperature effect on root carbon emission was explained by Figures $7(a)$ and $7(b)$. Measurements of fine root (Figure 7(a)) and rhizome (Figure $7(b))$ were performed separately to estimate their contribution to total root carbon emission and their seasonal variations. Temperature effect on fine root and rhizome was very significant which was explained by $R^{2}=0.96$ and $R^{2}=$
0.97 , respectively. The coefficient of temperature sensitivity $\left(Q_{10}\right)$ of carbon emission from fine root and rhizome was 2.3 and 1.9, respectively. Higher $Q_{10}$ of fine root was obtained compared to the rhizome because fine roots are more active and sensitive than the rhizomes during growing period in the temperate perennial grassland.

The regression equations obtained from the temperature effect on root carbon emission were used to analyze seasonal variations in carbon emissions from root during the study period as represented in Figure 8. Root carbon emission was increased with increasing temperature during growing season and it was peaked at $208.4 \mathrm{mg} \mathrm{CO}_{2} \mathrm{~m}^{-2} \mathrm{~h}^{-1}$ for fine root and $149.6 \mathrm{mg} \mathrm{CO}_{2} \mathrm{~m}^{-2} \mathrm{~h}^{-1}$ for rhizome in August from 2007 to 2010 . Fine root contributed higher than the rhizome to the total root carbon emission; the contribution of it was increased in mid- and late growing season (Figure 8).

Below-ground biomass was increased with progressing growing season. The variations of soil carbon emission and root carbon emission with the changes in below-ground biomass from 2007 to 2010 were explained in Figure 9. Both soil carbon emission and root carbon emission increased with increasing growing season temperature and were peaked in August (midgrowing season) and decreased with decreasing temperature towards the end of growing season. The difference between soil carbon emission and root carbon emission is the microbial or heterotrophic carbon emission. Contribution of root carbon emission to total soil carbon emission ranged from 24 to $30 \%$. Therefore, root carbon emission contributed about $1 / 4$ th of the total soil carbon emission and remaining higher contribution was made by heterotrophic carbon emission. 


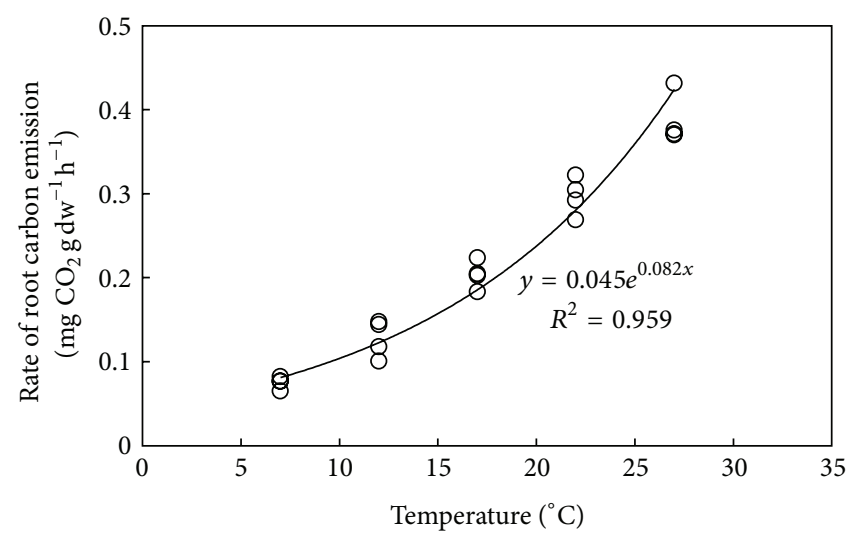

(a)

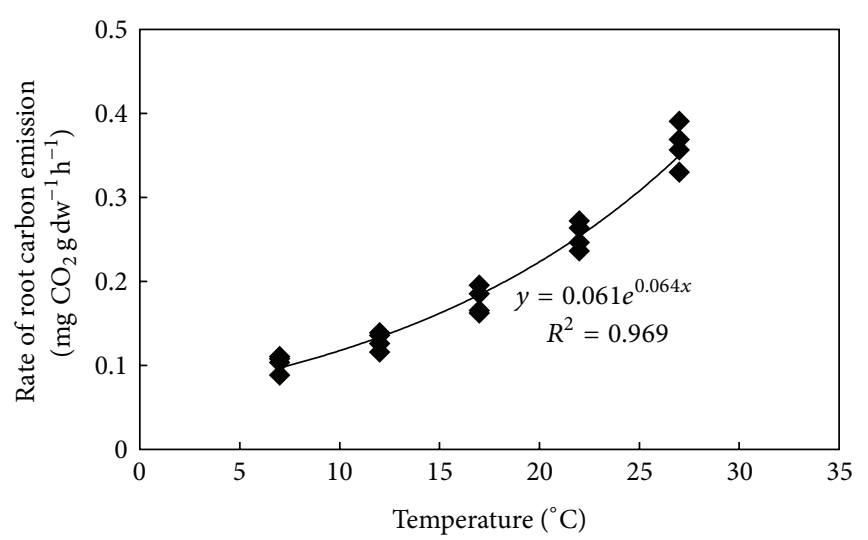

(b)

FIgURE 7: Temperature effect on root carbon emission (a) fine root and (b) rhizome in August 2007.

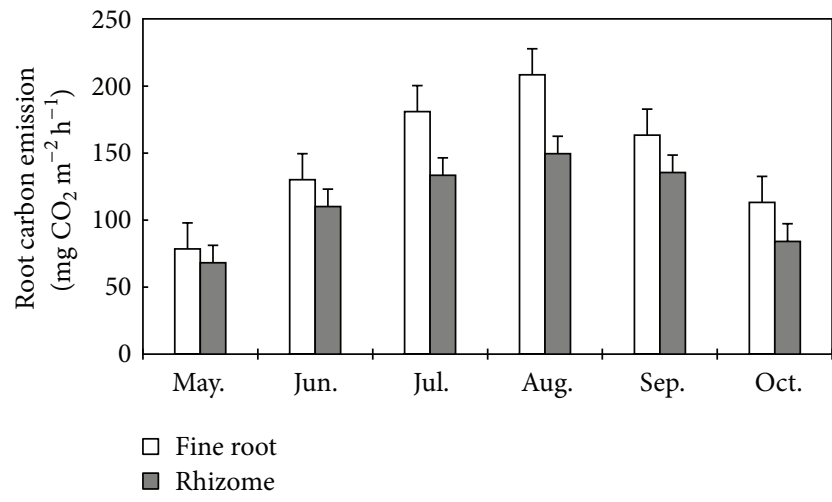

FIGURE 8: Seasonal variations of root carbon emission of four years on average (2007 to 2010).

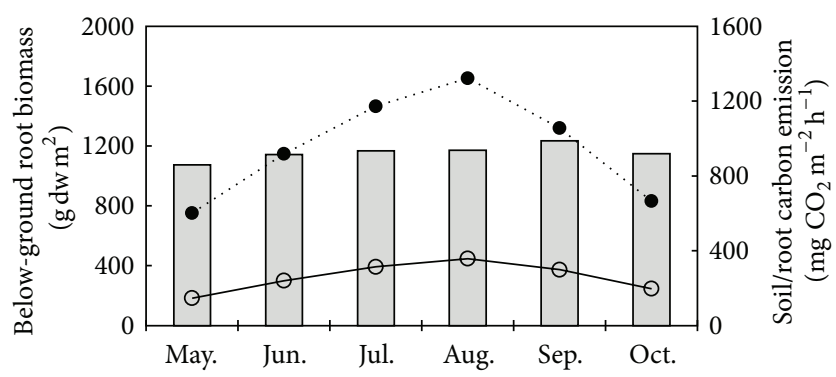

FIGURE 9: Variations of soil carbon emission (filled circles) and root carbon emission (open circles) with the changes of below-ground biomass (bars) of four years on average (2007 to 2010).

\section{Discussion}

Common ecosystem variables, light, temperature, precipitation, and growth, can effectively predict carbon sequestration and carbon emission in grassland during growing period which has been reported by Flanagan et al. [61], Hui et al. [62], and Nagy et al. [38], and temperature is the best confounding abiotic factor determining soil carbon emission that is proven by significant $\left(R^{2}=0.83\right)$ positive exponential relationship between soil carbon emission and soil temperature (Figure 3(a)) obtained in this study. Such relation is consistent with the studies $[50,63]$ in grasslands, $[51,64]$ in forest, and $[65]$ in desert shrubland.

The higher range (438 to $1642 \mathrm{mg} \mathrm{CO}_{2} \mathrm{~m}^{-2} \mathrm{~h}^{-1}$ ) of soil carbon emission obtained during growing season of this study was comparable with the range (790 to $1828 \mathrm{mg}$ $\mathrm{CO}_{2} \mathrm{~m}^{-2} \mathrm{~h}^{-1}$ ) obtained in $\mathrm{C}_{3} / \mathrm{C}_{4}$ grassland in Japan and also followed similar trend of lowest soil carbon emission in early growing season (April-May) and highest in midgrowing season in August [66]. The similar range (261 and $1361 \mathrm{mg}$ $\mathrm{CO}_{2} \mathrm{~m}^{-2} \mathrm{~h}^{-1}$ ) of soil carbon emission was also reported by Yan et al. [67] in Chinese poplar plantation comparable to our study. The reason for higher range of soil carbon emission in growing season of this study was owing to the lowest soil temperature in May and that was the period after 4/5 months of long snowy winter so as vegetation of the grassland was almost dead and the highest soil temperature was reached in August after the period of plentiful rainfall, and sufficient quantity of plant biomass was reached with grass growth in July. Other reports ( 47 to $745 \mathrm{mg} \mathrm{CO}_{2} \mathrm{~m}^{-2} \mathrm{~h}^{-1}$ ) in perennial Mongolian grassland [68] during growing season and (24 and $730 \mathrm{mg} \mathrm{CO}_{2} \mathrm{~m}^{-2} \mathrm{~h}^{-1}$ ) in northern Chinese forest [69] (63 and $306 \mathrm{mg} \mathrm{CO}_{2} \mathrm{~m}^{-2} \mathrm{~h}^{-1}$ ) in arid shrubland in Spain [35], and (73 and $225 \mathrm{mg} \mathrm{CO}_{2} \mathrm{~m}^{-2} \mathrm{~h}^{-1}$ ) in different subtropical Chinese forest [51] in growing and nongrowing season have lower range of soil carbon emission than this study; however all the values were not exactly the same and varying each other. McCulley et al. [70] suggested that mean soil organic carbon in forest can be as much as two times larger compared to increased soil carbon emission in grasslands, although soil carbon emissions were comparable and lower/higher in both forest and grassland. Therefore, soil carbon emission is determined by environmental variables, vegetation, land use change, and geographical locations which are mostly not the same and variable.

$Q_{10}$ temperature response of soil carbon emission value 2.1 of this study (Figure 3) falls within 1.5 and 6.3 [50, 63, 71, 
72] reported in some temperate ecosystems and is consistent with 2.4 [73], 2.3 [74] in grasslands and 2.1-2.7 [51] and 2.14.7 [64] in forests. The range (3.4-5.6) of $Q_{10}$ values reported by Davidson et al. [71] in a temperate mixed hardwood forest was much higher than some previous studies, and it was attributed by contribution of root to the soil carbon emission and variations due to temperature, precipitation, and soil microclimate.

The temperature effect of soil carbon emission was not affected $\left(R^{2}=0.018\right)$ by the soil water content in our measurement period (Figure 3(b)), but Inoue and Koizumi [75] observed a positive linear relationship $\left(R^{2}=0.55\right)$ only in midgrowing season (July-September); however soil moisture is the determinant abiotic factor of soil carbon emission [71, 72, 76, 77]. Zhou et al. [78] observed both aboveground biomass and soil carbon emission increased linearly with mean annual precipitation in Southern Great Plains, USA, and not only summer rainfall but also winter snow accumulation in grassland affects carbon cycling processes in winter and subsequent summer [79]. Greater soil water facilitates microbial decomposition of organic matter and increases heterotrophic carbon emission [80] and increases above-ground and below-ground plant and associated vegetation carbon emission [81, 82]. The unclear effect of soil water content on soil carbon emission of our study might be owing to the variations in measurement point, effect of removing grass inside the soil collar and single measurement in a month. Although effect of soil moisture on soil carbon emission is more complex and depends on site specific soil parameters [83], hence long-term continuous measurement might be useful to confound the relation.

Significant seasonal variations in soil carbon emission were observed in four years (Figure 4), and increasing temperature, precipitation, and plant growth are the fundamental factors that result in increasing soil carbon emission during growing season. Maximum values of monthly soil carbon emissions in 2007 (1285 mg CO $\left.\mathrm{m}^{-2} \mathrm{~h}^{-1}\right), 2008$ (1305 mg $\left.\mathrm{CO}_{2} \mathrm{~m}^{-2} \mathrm{~h}^{-1}\right)$, and $2009\left(1285 \mathrm{mg} \mathrm{CO}_{2} \mathrm{~m}^{-2} \mathrm{~h}^{-1}\right.$ ) were nearly equal and comparable with each other, but it is slightly higher (1414 $\mathrm{mg} \mathrm{CO}_{2} \mathrm{~m}^{-2} \mathrm{~h}^{-1}$ ) in 2010 (Figure 4) which was owing to higher soil temperature and precipitation (Figure 1) in July and August than the previous years. However, the range of soil carbon emissions in each month for all years was nearly equal and they all followed similar trend of seasonal variations so that the values were comparable to each other. Due to the seasonal variations of soil carbon emission, estimation of annual soil carbon emission is effective and accurate, if it is separately made during growing season and nongrowing season followed by the separate measurement made in each month and it was supported by Wei et al. [69] and Yan et al. [67]. Our growing season soil carbon emissions (1082, 1134, 1090 , and $1187 \mathrm{~g} \mathrm{C} \mathrm{m}^{-2}$ ) in four years were consistent with the values $\left(997,1043\right.$, and $1358 \mathrm{~g} \mathrm{C} \mathrm{m}^{-2}$ ) reported by $\mathrm{Li}$ et al. [50]. The annual soil carbon emissions $(1448,1500,1459$, and $1544 \mathrm{~g} \mathrm{C} \mathrm{m}^{-2}$ ) of our study were comparatively higher than the values ( 395 to $973 \mathrm{~g} \mathrm{C} \mathrm{m}^{-2}$ ) reported by Wei et al. [69] in different Chinese grasslands and $\left(755,719\right.$, and $1037 \mathrm{~g} \mathrm{C} \mathrm{m}^{-2}$ in 2007, 2008, and 2009) by Inoue and Koizumi [75] in the same study site. The reason behind variations in soil carbon emission was owing to the variations in study area, use of separate equipments, and size of the chamber; the smaller the size of chamber, the higher the value of emission [75] and measurements time. Comparable annual soil carbon emissions (1151 and $1161 \mathrm{~g} \mathrm{C} \mathrm{m}^{-2}$ ) were reported by Li et al. [50] in grasslands and (1070 and $1246 \mathrm{~g} \mathrm{C} \mathrm{m}^{-2}$ ) Kang et al. [84] and (1115 $\left.\mathrm{g} \mathrm{C} \mathrm{m}^{-2}\right) \mathrm{Li}$ et al. [50] in different forest ecosystems.

Comparatively, the nongrowing season soil carbon emissions $\left(366,366,369\right.$, and $357 \mathrm{~g} \mathrm{C} \mathrm{m}^{-2}$ ) were lower than the growing season emission, but they were very close to each other and not much different due to similar climatic years without much varying soil temperature and precipitation between the years. A research conducted in the field has convincingly demonstrated that soil microbial activity occurs at freezing temperatures $[85,86]$ and soil could release $\mathrm{CO}_{2}$ when incubated in the laboratory at freezing temperatures down to $-39^{\circ} \mathrm{C}[86]$. Therefore, comparing measurements of soil carbon emission taken annually with those taken during growing season is important for accurately estimating annual carbon budgets, modeling the effects of climate changes on soil carbon storage and release to the atmosphere [87] and calculating below-ground carbon allocation by plants [26].

Contribution of nongrowing season (Nov.-Apr., 23 to $25 \%$ ) and snow covered season (Dec.-Mar., 14 to $17 \%$ ) to annual soil carbon emission of this study is well within the range $(8-50 \%)$ reported in alpine ecosystems $[88,89]$ and higher than the range $(3.48-7.30 \%)$ reported in meadow grasslands, North China [69]. Snow covered season (Nov.Feb.) soil carbon emission should be included while estimating annual soil carbon emission because soil surface continuously emits carbon during nongrowing season and even from the snow covered surface when the emission remains low and constant $[90,91]$ and the inclusion of wintertime emission into annual carbon budgets could increase the annual carbon efflux of arctic tundra ecosystems by $17 \%$ and change some ecosystems from net annual sinks to net sources of carbon to the atmosphere [92]. Brooks et al. [93] reported that annual carbon sequestration is overestimated by $72 \%$ in deciduous forests and $111 \%$ in coniferous forests when winter soil carbon emission is not included. The one-fourth (1/4th) of our annual soil carbon emission was contributed by nongrowing season emission; therefore including nongrowing season measurements of respiration is needed to attain a more precise estimate of annual ecosystem carbon balance [47].

The annual soil carbon emissions 1448, 1500, 1459, and $1544 \mathrm{~g} \mathrm{C} \mathrm{m}^{-2}$ in consecutive years (Table 1) are slightly variable and the variations derived from increased/decreased growing season soil carbon emissions are owing to altering abiotic (climatic and growth) and biotic factors (root and microbial). Our annual soil carbon emissions are well within the range (698 to $1861 \mathrm{~g} \mathrm{C} \mathrm{m}^{-2}$ ) obtained in different land use change sites in south-east China [51]. Four consecutive years' average soil carbon emissions in growing season (1123 $\mathrm{g} \mathrm{C} \mathrm{m}^{-2}$ ), nongrowing season $\left(364 \mathrm{~g} \mathrm{C} \mathrm{m}^{-2}\right)$, and annual emissions $\left(1488 \mathrm{~g} \mathrm{C} \mathrm{m}^{-2}\right)$ of this study might be higher because these are quite site specific and include higher role of soil temperature and precipitation on microbial activities 
[29, 94]. More recently, estimates of global terrestrial soil carbon emission to the atmosphere have improved substantially, both in accuracy and number, especially in relation to different biomass [95]. The interannual variability of soil carbon emissions is very common; values are not exactly equal even in noncontrasting years resulting in that the rate of emission is controlled by abiotic and biotic environment and not accurately estimated but can be ranged after a long run of observations.

Atmospheric carbon sequestered during photosynthesis is accumulated in plant biomass which is not consistent in different seasons and years. Hence, seasonal and interannual variation in plant productivity is very common in grasslands $[38,96]$ due to variations in amount $[97,98]$ and pattern $[99,100]$ of annual precipitation or both [101, 102]. IPCC 2007 [10] reported that total precipitation (rainfall) amounts and frequency of extreme rainfall, drought events have projected, which may have greater impacts on ecosystem carbon cycling than the singular or combined effects of rising $\mathrm{CO}_{2}$ and temperature [103]. Higher above-ground biomass production reported in August 2008 of this study was owing to increased precipitation from March to June and constant but higher air temperature in July and August (Figure 1) that might be favorable to increase plant growth. In grassland ecosystems, variation in production at the seasonal scale (month) may be more sensitive and complex than response to climatic change at the annual scale. Therefore, Piao et al. [104] reported that the influence of climate on the vegetation activity of temperate grasslands in China varied between the growing seasons, and increased vegetation productivity was closely coupled with climate warming. The warm-season grasses grow with increasing temperature and precipitation in some limit. The variable temperature, precipitation, and grazing might be cause of comparatively lower productivity in growing season 2010. However, grazing directly affects growth in grasses and it facilitates rapid growth resulting in increase in plant biomass [105]. This is common in $Z$. japonica grasslands, although growth declines when grazing intensity exceeds the grasses' regrowth rate [106-108]. Similarly, seasonal and interannual variations of below-ground compartment which represents half of the total grassland production [109] are also critical for ecosystem carbon cycling. The seasonal variations of below-ground biomass in this study were not much higher which is consistent with the report in temperate grasslands of Oklahoma [78].

Carbon emission increases with increasing plant biomass due to higher rate of respiration from large respiratory surface (Figure 6) and the above-ground plant biomass is the result (gross primary productivity, GPP) obtained from photosynthesis and respiration. Mechanism of exchanging carbon during photosynthesis and autotrophic (plant)/heterotrophic (microbial) respiration between atmosphere and ecosystem is a process of carbon cycling. The autotrophic respiration is limited by photosynthesis and biomass maintenance costs which is sensitive to environmental factors commonly temperature and precipitation. Rate of carbon emission either autotrophic or heterotrophic is dependent on temperature, precipitation, and growth, but more sensitive to the changing temperature. However, growth is more sensitive to precipitation than temperature in warm-season grassland; higher precipitation suppresses soil carbon emission even at high temperature due to capillary effect on soil after some hours of rainfall and snow melt. In the same way, higher soil temperature suppresses soil carbon emission by removing soil water availability and declines plant growth, and plant productivity benefit of higher GPP is offset to some extent by the loss of higher autotrophic respiration [110]. Therefore, increased above-ground biomass in August 2008 was owing to favorable higher temperature and precipitation at the time of grass growth.

The significant (fine root, $R^{2}=0.96$, and rhizome, $R^{2}=$ 0.97) temperature effect on root carbon emission (Figure 7) at pick growing season showed higher seasonal variations of root carbon emissions from below-ground surface (Figure 8). The microbial carbon emission was higher than the root carbon emission in four years, although it is difficult to measure microbial carbon emission directly; the difference between soil and root carbon emission is the microbial carbon emission and was calculated. Combining microbial and root carbon emission, large amount of carbon had been estimated which continuously released from the grassland. Contribution of root carbon emission to the total soil carbon emission ranging from 24 to $30 \%$ in this study is well within the range $15-70 \%$ ([111-113]; 22-53\%); higher range (10-90\%) of contribution was also reported by Hanson et al. [114] and $<70 \%$ was reported by Hunt et al. [12] in dry grassland. The recent reviews have suggested that contribution of autotrophic and microbial carbon emission accounts for approximately half of the total soil carbon emission [114116]. However, these estimates showed considerable variation because of ecosystem diversity and potential biases in the different techniques and time scales used [28] and also with the variations in microbial carbon emissions in grazing grassland that are strongly site-specific.

\section{Conclusion}

Mechanisms of carbon cycling comprise carbon sequestration and carbon emission during photosynthesis and respiration which is expressed by plant productivity and carbon loss by root and microbial respiration. Seasonal and interannual variations in soil carbon emission were directed by soil temperature, but the role of precipitation for the variation in soil carbon emission was not established in this study. Hence, this indicated that soil temperature exerts a stronger control than soil water on soil carbon emission in grassland; however previous works have reported soil water as major control affecting soil carbon emission. Four consecutive years' average soil carbon emissions for growing season, nongrowing season, and annual emission were 1123, 364 , and $1488 \mathrm{~g} \mathrm{C} \mathrm{m}^{-2}$, respectively. Above-/below-ground biomass and soil carbon emission varied with variations in growing season temperature and precipitation. Root carbon emission was peaked in midgrowing season and about $1 / 4$ th of soil carbon emission was contributed by microbial or heterotrophic carbon emission. Grazing intensity directly affects above-ground biomass compared to the below-ground 
biomass. Our long-term estimation of carbon cycling concluded that seasonal and interannual variations are very common in carbon sequestration and emission in grassland ecosystem.

\section{Conflict of Interests}

The authors declare that there is no conflict of interests regarding the publication of this paper.

\section{Acknowledgments}

The authors thank Nepal Academy of Science and Technology, Khumaltar, Lalitpur, and River Basin Research Center, Gifu University, Gifu, Japan, to prepare the paper. They extend their thanks to the reviewers for their valuable suggestions.

\section{References}

[1] P. M. Fearnside, "Deforestation in Brazilian Amazonia: history, rates, and consequences," Conservation Biology, vol. 19, no. 3, pp. 680-688, 2005.

[2] D. S. Alves, D. C. Morton, M. Batistella, D. A. Roberts, and J. R. C. Souza, "The changing rates and patterns of deforestation and land use in Brazilian Amazonia," in American Geophysical Union, M. Keller, M. Bustamante, J. Gash, and P. S. Dias, Eds., pp. 11-23, American Geophysical Union, Washington, DC, USA, 2009.

[3] K. Booker, L. Huntsinger, J. W. Bartolome, N. F. Sayre, and W. Stewart, "What can ecological science tell us about opportunities for carbon sequestration on arid rangelands in the United States?" Global Environmental Change, vol. 23, no. 1, pp. 240251, 2013.

[4] G. A. Buyanovsky, C. L. Kucera, and G. H. Wagner, "Comparative analyses of carbon dynamics in native and cultivated ecosystems," Ecology, vol. 68, no. 6, pp. 2023-2031, 1987.

[5] W. J. Parton, J. M. O. Scurlock, D. S. Ojima, D. S. Schimel, and D. O. Hall, "Impact of climate change on grassland production and soil carbon worldwide," Global Change Biology, vol. 1, no. 1, pp. 13-22, 1995.

[6] L. C. Johnson and J. R. Matchett, "Fire and grazing regulate belowground processes in tallgrass prairie," Ecology, vol. 82, no. 12, pp. 3377-3389, 2001.

[7] N. Priante-Filho, G. L. Vourlitis, M. M. S. Hayashi et al., "Comparison of the mass and energy exchange of a pasture and a mature transitional tropical forest of the southern Amazon Basin during a seasonal transition," Global Change Biology, vol. 10, no. 5, pp. 863-876, 2004.

[8] C. von Randow, A. O. Manzi, B. Kruijt et al., "Comparative measurements and seasonal variations in energy and carbon exchange over forest and pasture in South West Amazonia," Theoretical and Applied Climatology, vol. 78, no. 1-3, pp. 5-26, 2004.

[9] S. R. Saleska, K. Didan, A. R. Huete, and H. R. da Rocha, "Amazon forests green-up during 2005 drought," Science, vol. 318, no. 5850, p. 612, 2007.

[10] IPCC, Climate Change 2007: The Physical Science Basis, Summary for Policy Makers, IPCC Secretariat, Geneva, Switzerland, 2007.
[11] A. E. Suyker, S. B. Verma, and G. G. Burba, "Interannual variability in net $\mathrm{CO}_{2}$ exchange of a native tallgrass prairie," Global Change Biology, vol. 9, no. 2, pp. 255-265, 2003.

[12] J. E. Hunt, F. M. Kelliher, T. M. McSeveny, D. J. Ross, and D. Whitehead, "Long-term carbon exchange in a sparse, seasonally dry tussock grassland," Global Change Biology, vol. 10, no. 10, pp. 1785-1800, 2004.

[13] K. A. Novick, P. C. Stoy, G. G. Katul et al., "Carbon dioxide and water vapor exchange in a warm temperate grassland," Oecologia, vol. 138, no. 2, pp. 259-274, 2004.

[14] R. Amundson, A. T. Austin, E. A. G. Schuur et al., "Global patterns of the isotopic composition of soil and plant nitrogen," Global Biogeochemical Cycles, vol. 17, no. 1, p. 103, 2003.

[15] J. Grace, "Understanding and managing the global carbon cycle," Journal of Ecology, vol. 92, no. 2, pp. 189-202, 2004.

[16] C. Tamocai, J. G. Canadell, E. A. G. Schuur, P. Kuhry, G. Mazhitova, and S. Zimov, "Soil organic carbon pools in the northern circumpolar permafrost region," Global Biogeochemical Cycles, vol. 23, no. 2, Article ID GB2023, 2009.

[17] W. H. Schlesinger and J. A. Andrews, "Soil respiration and the global carbon cycle," Biogeochemistry, vol. 48, no. 1, pp. 7-20, 2000.

[18] I. C. Prentice, G. D. Farquhar, M. J. R. Fasham et al., "The carbon cycle and atmospheric carbon dioxide," in Climate Change, J. T. Houghton, Y. Ding, D. J. Griggs et al., Eds., pp. 183-237, Cambridge University Press, Cambridge, UK, 2001.

[19] A. B. Frank, "Carbon dioxide fluxes over a grazed prairie and seeded pasture in the Northern Great Plains," Environmental Pollution, vol. 116, no. 3, pp. 397-403, 2002.

[20] J. D. Reeder and G. E. Schuman, "Influence of livestock grazing on $\mathrm{C}$ sequestration in semi-arid mixed-grass and short-grass rangelands," Environmental Pollution, vol. 116, no. 3, pp. 457463, 2002.

[21] K. Franzluebbers, A. J. Franzluebbers, and M. D. Jawson, "Environmental controls on soil and whole-ecosystem respiration from a tallgrass prairie," Soil Science Society of America Journal, vol. 66, no. 1, pp. 254-262, 2002.

[22] J. M. Adams, H. Faure, L. Faure-Denard, J. M. McGlade, and F. I. Woodward, "Increases in terrestrial carbon storage from the Last Glacial Maximum to the present," Nature, vol. 348, no. 6303, pp. 711-714, 1990.

[23] N. H. Batjes, "Mitigation of atmospheric $\mathrm{CO}_{2}$ concentrations by increased carbon sequestration in the soil," Biology and Fertility of Soils, vol. 27, no. 3, pp. 230-235, 1998.

[24] J. M. O. Scurlock and D. O. Hall, "The global carbon sink: a grassland perspective," Global Change Biology, vol. 4, no. 2, pp. 229-233, 1998.

[25] P. M. Cox, R. A. Betts, C. D. Jones, S. A. Spall, and I. J. Totterdell, "Acceleration of global warming due to carbon-cycle feedbacks in a coupled climate model," Nature, vol. 408, no. 6809, pp. 184$187,2000$.

[26] C. P. Giardina and M. G. Ryan, "Evidence that decomposition rates of organic carbon in mineral soil do not vary with temperature," Nature, vol. 404, no. 6780, pp. 858-861, 2000.

[27] I. A. Janssens, H. G. Matteucci, A. S. Kowalski et al., "Productivity over shadows temperature in determining soil and ecosystem respiration across European forests," Global Change Biology, vol. 7, no. 3, pp. 269-278, 2001.

[28] X. Zhou, S. Wan, and Y. Luo, "Source components and interannual variability of soil $\mathrm{CO}_{2}$ efflux under experimental warming and clipping in a grassland ecosystem," Global Change Biology, vol. 13, no. 4, pp. 761-775, 2007. 
[29] W. Liu, Z. Zhang, and S. Wan, "Predominant role of water in regulating soil and microbial respiration and their responses to climate change in a semiarid grassland," Global Change Biology, vol. 15, no. 1, pp. 184-195, 2009.

[30] M. U. F. Kirschbaum, "Will changes in soil organic carbon act as a positive or negative feedback on global warming?" Biogeochemistry, vol. 48, no. 1, pp. 21-51, 2000.

[31] K. M. Goh, "Carbon sequestration and stabilization in soils: implications for soil productivity and climate change," Soil Science \& Plant Nutrition, vol. 50, no. 4, pp. 467-476, 2004.

[32] R. Lal, "Soil carbon sequestration to mitigate climate change," Geoderma, vol. 123, no. 1-2, pp. 1-22, 2004.

[33] L. Xu and D. D. Baldocchi, "Seasonal variation in carbon dioxide exchange over a Mediterranean annual grassland in California," Agricultural and Forest Meteorology, vol. 123, no. 1-2, pp. 79-96, 2004.

[34] G. Saiz, C. Green, K. Butterbach-Bahl, R. Kiese, V. Avitabile, and E. P. Farrell, "Seasonal and spatial variability of soil respiration in four Sitka spruce stands," Plant and Soil, vol. 287, no. 1-2, pp. 161-176, 2006.

[35] C. Oyonarte, A. Rey, J. Raimundo, I. Miralles, and P. Escribano, "The use of soil respiration as an ecological indicator in arid ecosystems of the SE of Spain: spatial variability and controlling factors," Ecological Indicators, vol. 14, no. 1, pp. 40-49, 2012.

[36] Y. Dong, Y. Qi, J. Liu et al., "Variation characteristics of soil respiration fluxes in four types of grassland communities under different precipitation intensity," Chinese Science Bulletin, vol. 50, no. 6, pp. 583-591, 2005.

[37] V. Jaksic, G. Kiely, J. Albertson et al., "Net ecosystem exchange of grassland in contrasting wet and dry years," Agricultural and Forest Meteorology, vol. 139, no. 3-4, pp. 323-334, 2006.

[38] Z. Nagy, K. Pintér, S. Czóbel et al., "The carbon budget of semiarid grassland in a wet and a dry year in Hungary," Agriculture, Ecosystems and Environment, vol. 121, no. 1-2, pp. 21-29, 2007.

[39] P. C. Stoy, A. D. Richardson, D. D. Baldocchi et al., "Biosphereatmosphere exchange of $\mathrm{CO}_{2}$ in relation to climate: a crossbiome analysis across multiple time scales," Biogeosciences, vol. 6, no. 10, pp. 2297-2312, 2009.

[40] E. J. Moors, C. Jacobs, W. Jans et al., "Variability in carbon exchange of European croplands," Agriculture, Ecosystems and Environment, vol. 139, no. 3, pp. 325-335, 2010.

[41] A. Noormets, M. J. Gavazzi, S. G. McNulty et al., "Response of carbon fluxes to drought in a coastal plain loblolly pine forest," Global Change Biology, vol. 16, no. 1, pp. 272-287, 2010.

[42] A. Rodrigues, G. Pita, J. Mateus et al., "Eight years of continuous carbon fluxes measurements in a Portuguese eucalypt stand under two main events: drought and felling," Agricultural and Forest Meteorology, vol. 151, no. 4, pp. 493-507, 2011.

[43] J. W. Raich and W. H. Schlesinger, "The global carbon dioxide flux in soil respiration and its relationship to vegetation and climate," Tellus B, vol. 44, no. 2, pp. 81-99, 1992.

[44] J. W. Raich and C. S. Potter, "Global patterns of carbon dioxide emissions from soils," Global Biogeochemical Cycles, vol. 9, no. 1, pp. 23-36, 1995.

[45] IPCC, Climate Change 2001: The Scientific Basis, Intergovernmental Panel on Climate Change, 2001, http://www.grida.no/ publications/other/ipcc_tar/?src=/climate/ipcc_tar/wgl/index .htm.

[46] D. D. Baldocchi, C. A. Vogel, and B. Hall, "Seasonal variation of carbon dioxide exchange rates above and below a boreal jack pine forest," Agricultural and Forest Meteorology, vol. 83, no. 1-2, pp. 147-170, 1997.
[47] D. Dhital, Y. Yashiro, T. Ohtsuka, H. Noda, Y. Shizu, and H. Koizumi, "Carbon dynamics and budget in a Zoysia japonica grassland, central Japan," Journal of Plant Research, vol. 123, no. 4, pp. 519-530, 2010.

[48] B. Marcolla, A. Cescatti, G. Manca et al., "Climatic controls and ecosystem responses drive the inter-annual variability of the net ecosystem exchange of an alpine meadow," Agricultural and Forest Meteorology, vol. 151, no. 9, pp. 1233-1243, 2011.

[49] J. C. Yuste, I. A. Janssens, A. Carrara, L. Meiresonne, and R. Ceulemans, "Interactive effects of temperature and precipitation on soil respiration in a temperate maritime pine forest," Tree Physiology, vol. 23, no. 18, pp. 1263-1270, 2003.

[50] H.-J. Li, J.-X. Yan, X.-F. Yue, and M.-B. Wang, "Significance of soil temperature and moisture for soil respiration in a Chinese mountain area," Agricultural and Forest Meteorology, vol. 148, no. 3, pp. 490-503, 2008.

[51] H. Sheng, Y. Yang, Z. Yang et al., "The dynamic response of soil respiration to land-use changes in subtropical China," Global Change Biology, vol. 16, no. 3, pp. 1107-1121, 2010.

[52] X. Yu, T. Zha, Z. Pang et al., "Response of soil respiration to soil temperature and moisture in a 50-year-old oriental arborvitae plantation in China," PLoS ONE, vol. 6, no. 12, Article ID e28397, 2011.

[53] R. A. Chimner, "Soil respiration rates of tropical peatlands in Micronesia and Hawaii," Wetlands, vol. 24, no. 1, pp. 51-56, 2004.

[54] T. E. Twine and C. J. Kucharik, "Climate impacts on net primary productivity trends in natural and managed ecosystems of the central and eastern United States," Agricultural and Forest Meteorology, vol. 149, no. 12, pp. 2143-2161, 2009.

[55] D. Dhital, H. Muraoka, Y. Yashiro, Y. Shizu, and H. Koizumi, "Measurement of net ecosystem production and ecosystem respiration in a Zoysia japonica grassland, central Japan, by the chamber method," Ecological Research, vol. 25, no. 2, pp. 483493, 2010.

[56] E. P. Hamerlynck, R. L. Scott, M. S. Moran, T. O. Keefer, and T. E. Huxman, "Growing season ecosystem and leaf-level gas exchange of an exotic and native semiarid bunchgrass," Oecologia, vol. 163, no. 3, pp. 561-570, 2010.

[57] D. Dragoni, H. P. Schmid, C. A. Wayson, H. Potter, C. S. B. Grimmond, and J. C. Randolph, "Evidence of increased net ecosystem productivity associated with a longer vegetated season in a deciduous forest in South-Central Indiana, USA," Global Change Biology, vol. 17, no. 2, pp. 886-897, 2011.

[58] M. L. Thomey, S. L. Collins, R. Vargas et al., "Effect of precipitation variability on net primary production and soil respiration in a Chihuahuan Desert grassland," Global Change Biology, vol. 17, no. 4, pp. 1505-1515, 2011.

[59] C. B. Field, D. B. Lobell, H. A. Peters, and N. R. Chiariello, "Feedbacks of terrestrial ecosystems to climate change," Annual Review of Environment and Resources, vol. 32, pp. 1-29, 2007.

[60] L. H. Li and Z. Z. Chen, "Soil respiration in grassland communities in the world," Chinese Journal of Ecology, vol. 17, no. 4, pp. 45-51, 1998 (Chinese).

[61] L. B. Flanagan, L. A. Wever, and P. J. Carlson, "Seasonal and interannual variation in carbon dioxide exchange and carbon balance in a northern temperate grassland," Global Change Biology, vol. 8, no. 7, pp. 599-615, 2002.

[62] D. Hui, Y. Luo, and G. Katul, "Partitioning interannual variability in net ecosystem exchange between climatic variability and functional change," Tree Physiology, vol. 23, no. 7, pp. 433-442, 2003. 
[63] G. Cao, Y. Tang, W. Mo, Y. Wang, Y. Li, and X. Zhao, “Grazing intensity alters soil respiration in an alpine meadow on the Tibetan plateau," Soil Biology and Biochemistry, vol. 36, no. 2, pp. 237-243, 2004.

[64] J. Luo, Y. Chen, Y. Wu, P. Shi, J. She, and P. Zhou, “Temporalspatial variation and controls of soil respiration in different primary succession stages on glacier forehead in Gongga Mountain, China," PLoS ONE, vol. 7, no. 8, Article ID e42354, 2012.

[65] L. H. Zhang, Y. N. Chen, R. F. Zhao, and W. H. Li, "Significance of temperature and soil water content on soil respiration in three desert ecosystems in Northwest China," Journal of Arid Environments, vol. 74, no. 10, pp. 1200-1211, 2010.

[66] W. Wang, K. Ohse, J. Liu, W. Mo, and T. Oikawa, "Contribution of root respiration to soil respiration in a $\mathrm{C}_{3} / \mathrm{C}_{4}$ mixed grassland," Journal of Biosciences, vol. 30, no. 4, pp. 507-514, 2005.

[67] M. Yan, X. Zhang, G. Zhou, J. Gong, and X. You, “Temporal and spatial variation in soil respiration of poplar plantations at different developmental stages in Xinjiang, China," Journal of Arid Environments, vol. 75, no. 1, pp. 51-57, 2011.

[68] Z. Jin, Y. S. Dong, Y. C. Qi, and Z. S. An, "Soil respiration and net primary productivity in perennial grass and desert shrub ecosystems at the Ordos Plateau of Inner Mongolia, China," Journal of Arid Environments, vol. 74, no. 10, pp. 1248-1256, 2010.

[69] W. Wang, S. Peng, T. Wang, and J. Fang, "Winter soil $\mathrm{CO}_{2}$ efflux and its contribution to annual soil respiration in different ecosystems of a forest-steppe ecotone, North China," Soil Biology and Biochemistry, vol. 42, no. 3, pp. 451-458, 2010.

[70] R. L. McCulley, S. R. Archer, T. W. Boutton, F. M. Hons, and D. A. Zuberer, "Soil respiration and nutrient cycling in wooded communities developing in grassland," Ecology, vol. 85, no. 10, pp. 2804-2817, 2004.

[71] E. A. Davidson, E. Belk, and R. D. Boone, "Soil water content and temperature as independent or confounded factors controlling soil respiration in a temperate mixed hardwood forest," Global Change Biology, vol. 4, no. 2, pp. 217-227, 1998.

[72] A. Rey, E. Pegoraro, V. Tedeschi, I. de Parri, P. G. Jarvis, and R. Valentini, "Annual variation in soil respiration and its components in a coppice oak forest in Central Italy," Global Change Biology, vol. 8, no. 9, pp. 851-866, 2002.

[73] P. C. Mielnick and W. A. Dugas, "Soil $\mathrm{CO}_{2}$ flux in a tallgrass prairie," Soil Biology and Biochemistry, vol. 32, no. 2, pp. 221228, 2000.

[74] E. A. Davidson, I. A. Janssens, and Y. Lou, "On the variability of respiration in terrestrial ecosystems: moving beyond $Q_{10}$," Global Change Biology, vol. 12, no. 2, pp. 154-164, 2006.

[75] T. Inoue and H. Koizumi, "Effects of environmental factors upon variation in soil respiration of a Zoysia japonica grassland, central Japan," Ecological Research, vol. 27, no. 2, pp. 445-452, 2012.

[76] R. L. McCulley, T. W. Boutton, and S. R. Archer, "Soil respiration in a subtropical savanna parkland: response to water additions," Soil Science Society of America Journal, vol. 71, no. 3, pp. 820828, 2007.

[77] S. Suh, E. Lee, and J. Lee, "Temperature and moisture sensitivities of $\mathrm{CO}_{2}$ efflux from lowland and alpine meadow soils," Journal of Plant Ecology, vol. 2, no. 4, pp. 225-231, 2009.

[78] X. Zhou, M. Talley, and Y. Luo, "Biomass, litter and soil respiration along a precipitation gradient in Southern Great Plains, USA," Ecosystems, vol. 12, no. 8, pp. 1369-1380, 2009.
[79] R. A. Chimner and J. M. Welker, "Ecosystem respiration responses to experimental manipulations of winter and summer precipitation in a Mixedgrass Prairie, WY, USA," Biogeochemistry, vol. 73, no. 1, pp. 257-270, 2005.

[80] S. E. Hobbie, J. P. Schimel, S. E. Trumbore, and J. R. Randerson, "Controls over carbon storage and turnover in high-latitude soils," Global Change Biology, vol. 6, no. 1, pp. 196-210, 2000.

[81] D. G. Milchunas, J. R. Forwood, and W. K. Lauenroth, "Productivity of long-term grazing treatments in response to seasonal precipitation," Journal of Range Management, vol. 47, no. 2, pp. 133-139, 1994.

[82] A. K. Knapp, J. M. Briggs, and J. K. Koelliker, "Frequency and extent of water limitation to primary production in a mesic temperate grassland," Ecosystems, vol. 4, no. 1, pp. 19-28, 2001.

[83] P. J. Howard, P. J. Loveland, R. I. Bradley, F. T. Dry, D. M. Howard, and D. C. Howard, "The carbon content of soil and its geographical distribution in Great Britain," Soil Use and Management, vol. 11, no. 1, pp. 9-15, 1995.

[84] S. Kang, S. Doh, D. Lee, D. Lee, V. L. Jin, and J. S. Kimball, "Topographic and climatic controls on soil respiration in six temperate mixed-hardwood forest slopes, Korea," Global Change Biology, vol. 9, no. 10, pp. 1427-1437, 2003.

[85] S. K. Schmidt and D. A. Lipson, "Microbial growth under the snow: implications for nutrient and allelochemical availability in temperate soils," Plant and Soil, vol. 259, no. 1-2, pp. 1-7, 2004.

[86] S. Nobrega and P. Grogan, "Deeper snow enhances winter respiration from both plant-associated and bulk soil carbon pools in birch hummock tundra," Ecosystems, vol. 10, no. 3, pp. 419-431, 2007.

[87] F. S. Chapin III, S. A. Zimov, G. R. Shaver, and S. E. Hobble, "CO${ }_{2}$ fluctuation at high latitudes," Nature, vol. 383, no. 6601, pp. 585-586, 1996.

[88] J. G. Vogel, D. W. Valentine, and R. W. Ruess, "Soil and root respiration in mature Alaskan black spruce forests that vary in soil organic matter decomposition rates," Canadian Journal of Forest Research, vol. 35, no. 1, pp. 161-174, 2005.

[89] A. Schindlbacher, S. Zechmeister-Boltenstern, G. Glatzel, and R. Jandl, "Winter soil respiration from an Austrian mountain forest," Agricultural and Forest Meteorology, vol. 146, no. 3-4, pp. 205-215, 2007.

[90] S. Mariko, N. Nishimura, W. Mo, Y. Matsui, T. Kibe, and H. Koizumi, "Winter $\mathrm{CO}_{2}$ flux from soil and snow surfaces in a cool-temperate deciduous forest, Japan," Ecological Research, vol. 15, pp. 363-372, 2000.

[91] P. Grogan, L. Illeris, A. Michelsen, and S. Jonasson, "Respiration of recently-fixed plant carbon dominates mid-winter ecosystem $\mathrm{CO}_{2}$ production in sub-arctic heath tundra," Climatic Change, vol. 50, no. 1-2, pp. 129-142, 2001.

[92] J. T. Fahnestock, M. H. Jones, and J. M. Welker, "Wintertime $\mathrm{CO}_{2}$ efflux from arctic soils: Implications for annual carbon budgets," Global Biogeochemical Cycles, vol. 13, no. 3, pp. 775779, 1999.

[93] P. D. Brooks, D. McKnight, and K. Elder, "Carbon limitation of soil respiration under winter snowpacks: potential feedbacks between growing season and winter carbon fluxes," Global Change Biology, vol. 11, no. 2, pp. 231-238, 2005.

[94] C. S. Sheik, W. H. Beasley, M. S. Elshahed, X. Zhou, Y. Luo, and L. R. Krumholz, "Effect of warming and drought on grassland microbial communities," The ISME Journal, vol. 5, no. 10, pp. 1692-1700, 2011. 
[95] B. Bond-Lamberty and A. Thomson, "Temperature-associated increases in the global soil respiration record," Nature, vol. 464, no. 7288, pp. 579-582, 2010.

[96] P. A. Fay, J. D. Carlisle, A. K. Knapp, J. M. Blair, and S. L. Collins, "Productivity responses to altered rainfall patterns in a $\mathrm{C}_{4}$-dominated grassland," Oecologia, vol. 137, no. 2, pp. 245-251, 2003.

[97] Y. Bai, X. Han, J. Wu, Z. Chen, and L. Li, "Ecosystem stability and compensatory effects in the Inner Mongolia grassland," Nature, vol. 431, no. 7005, pp. 181-184, 2004.

[98] I. Fabricante, M. Oesterheld, and J. M. Paruelo, "Annual and seasonal variation of NDVI explained by current and previous precipitation across Northern Patagonia," Journal of Arid Environments, vol. 73, no. 8, pp. 745-753, 2009.

[99] C. W. Harper, J. M. Blair, P. A. Fay, A. K. Knapp, and J. D. Carlisle, "Increased rainfall variability and reduced rainfall amount decreases soil $\mathrm{CO}_{2}$ flux in a grassland ecosystem," Global Change Biology, vol. 11, no. 2, pp. 322-334, 2005.

[100] A. M. Swemmer, A. K. Knapp, and H. A. Snyman, "Intraseasonal precipitation patterns and above-ground productivity in three perennial grasslands," Journal of Ecology, vol. 95, no. 4, pp. 780-788, 2007.

[101] S. Schwinning and O. E. Sala, "Hierarchy of responses to resource pulses in arid and semi-arid ecosystems," Oecologia, vol. 141, no. 2, pp. 211-220, 2004.

[102] W. W. Chou, W. L. Silver, R. D. Jackson, A. W. Thompson, and B. Allen-Diaz, "The sensitivity of annual grassland carbon cycling to the quantity and timing of rainfall," Global Change Biology, vol. 14, no. 6, pp. 1382-1394, 2008.

[103] J. F. Weltzin, M. E. Loik, S. Schwinning et al., "Assessing the response of terrestrial ecosystems to potential changes in precipitation," BioScience, vol. 53, no. 10, pp. 941-952, 2003.

[104] S. Piao, P. Friedlingstein, P. Ciais, L. Zhou, and A. Chen, "Effect of climate and $\mathrm{CO}_{2}$ changes on the greening of the Northern Hemisphere over the past two decades," Geophysical Research Letters, vol. 33, no. 23, Article ID L23402, 2006.

[105] Y. H. Gao, P. Luo, N. Wu, H. Chen, and G. X. Wang, "Grazing intensity impacts on carbon sequestration in an alpine meadow on the Eastern Tibetan Plateau," Journal of Agriculture and Biological Sciences, vol. 3, pp. 642-647, 2007.

[106] T. Y. Ito and S. Takatsuki, "Relationship between a high density of sika deer and productivity of the short-grass (Zoysia japonica) community: a case study on Kinkazan Island, northern Japan," Ecological Research, vol. 20, no. 5, pp. 573-579, 2005.

[107] S.-G. Li, J. Asanuma, W. Eugster et al., "Net ecosystem carbon dioxide exchange over grazed steppe in central Mongolia," Global Change Biology, vol. 11, no. 11, pp. 1941-1955, 2005.

[108] M. Takahashi, K. Ueda, H. Nakatsuji, and S. Kondo, "Effect of stocking rate on soil animal and microorganisms, inorganic nitrogen contents in soil, herbage production and nitrogen intake by dairy cows," Japanese Journal of Grassland Science, vol. 51, pp. 157-162, 2005.

[109] D. G. Milchunas and W. K. Lauenroth, "Belowground primary production by carbon isotope decay and long-term root biomass dynamics," Ecosystems, vol. 4, no. 2, pp. 139-150, 2001.

[110] Y. Malhi, "The productivity, metabolism and carbon cycle of tropical forest vegetation," Journal of Ecology, vol. 100, no. 1, pp. 65-75, 2012.

[111] C. L. Kucera and D. R. Kirkham, "Soil respiration studies in tall grass prairie in Missouri,” Ecology, vol. 52, pp. 912-915, 1971.
[112] S. R. Gupta and J. S. Singh, "Soil respiration in a tropical grassland," Soil Biology and Biochemistry, vol. 13, no. 4, pp. 261268, 1981.

[113] J. M. Norman, R. Garcia, and S. B. Verma, "Soil surface $\mathrm{CO}_{2}$ fluxes and the carbon budget of a grassland," Journal of Geophysical Research, vol. 97, no. 17, pp. 18845-18853, 1992.

[114] P. J. Hanson, N. T. Edwards, C. T. Garten, and J. A. Andrews, "Separating root and soil microbial contributions to soil respiration: a review of methods and observations," Biogeochemistry, vol. 48, no. 1, pp. 115-146, 2000.

[115] B. Bond-Lamberty, C. Wang, and S. T. Gower, "A global relationship between the heterotrophic and autotrophic components of soil respiration?" Global Change Biology, vol.10, no. 10, pp. 17561766, 2004.

[116] J.-A. Subke, I. Inglima, and M. F. Cotrufo, "Trends and methodological impacts in soil $\mathrm{CO}_{2}$ efflux partitioning: a metaanalytical review," Global Change Biology, vol. 12, no. 6, pp. 921-943, 2006. 

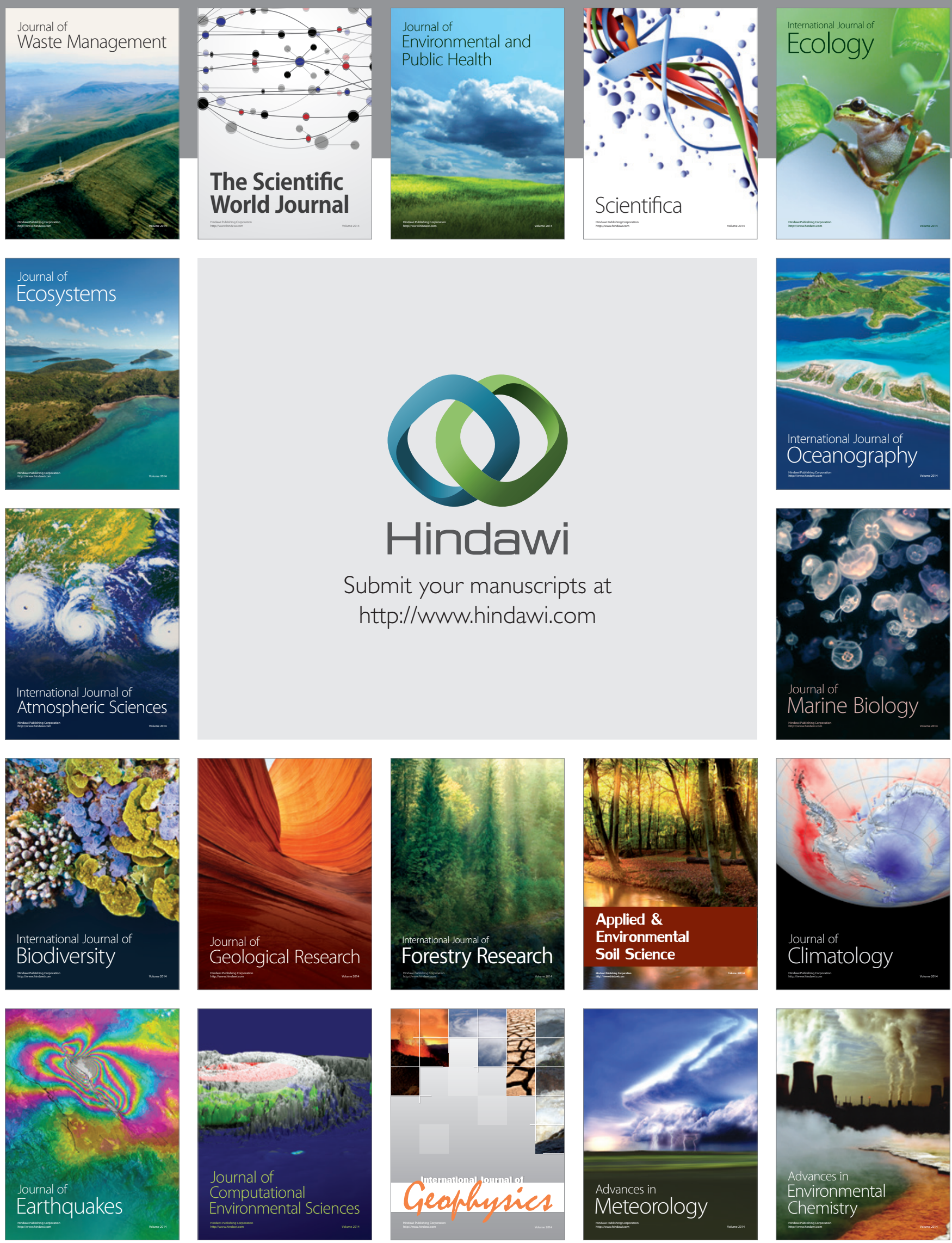